\title{
o jogo performático de oswald de andrade no poema "reivindicacão"
}

The performatic game of Oswald de Andrade in the poem "Reivindicação" Ellen Margareth Dias Ribeiro Araújo ${ }^{1}$

Resumo: Este estudo objetiva discutir a subjetividade lírica no poema "reivindicação", de Oswald de Andrade, escrito provavelmente na década de 1920. O poema "inédito" possibilita investigar a atuação do sujeito lírico em performances marcadas pela tensão ambígua entre o ficcional e o autobiográfico. Interessa evidenciar o vínculo sujeito lírico e sujeito empírico, disfarçado pelas máscaras do fingimento poético e que culmina no retorno do sujeito empírico ao poema, performando subjetividades como outro "eu".

Palavras-chave: Subjetividade lírica; Performances; Oswald de Andrade.

Abstract: This study aims to discuss lyrical subjectivity in the poem "reivindicação", by Oswald de Andrade, probably written in the 1920s. The "unpublished" poem makes it possible to investigate the actuation of the lyrical subject in performances marked by the ambiguous tension between the fictional and the autobiographical. It is interesting to highlight the link between the lyrical subject and the empirical subject, disguised by the masks of poetic pretense and which culminates in the return of the empirical subject to the poem, performing as another "me".

Keywords: Lyrical subjectivity; Performances; Oswald de Andrade.

1 Mestra (2018) e doutoranda em Estudos Literários pelo Programa de Pós-Graduação em Letras e Linguística da Universidade Federal de Goiás (UFG). E-mail: ellen_ribo1@hotmail.com. 


\section{introducão}

Este estudo discute a construção da subjetividade lírica no poema "reivindicação", de Oswald de Andrade. O texto pertence à seção "Poemas inéditos" na nova edição de Poesias reunidas Oswald de Andrade (2017). A análise detém-se no sujeito lírico em suas múltiplas configurações, em constante diálogo com o sujeito empírico (poeta). Por ser uma relação ambígua e dissonante, buscamos perceber o jogo performático, no qual atua o "eu" sob uma máscara ficcional, que guarda vestígios autobiográficos do poeta.

Esclarecemos que sujeito lírico ou sujeito poético é uma entidade fictícia, uma voz em enunciação. Como sujeito, é inscrito na história, fragmentado e de identidade descontínua. E pode, em alguma medida, aproximar-se do poeta. Sujeito empírico é o próprio poeta/autor, a pessoa do dia a dia, o cidadão do mundo, inscrito histórica e socialmente e que procura ausentar-se do poema. Esses conceitos, abalizados pela modernidade a partir de Baudelaire do final do século XIX e começo do XX, são referências para este estudo.

O termo performance, comumente utilizado pelo teatro e pela dança, atualmente abrange as mais diversas manifestações artísticas, inclusive a poesia. Pensamos performance no sentido de desempenho, atuação, representação. Não são acepções fechadas, mas ajudam-nos a perceber o sujeito em nova configuração. As expressões jogo performático e performances subjetivas referem-se ao jogo de mostrar e simular, às vozes encenadas disfarçadas pelas máscaras, tanto às ambivalências como às contradições, à sátira, à ironia, ao humor, ao fragmentário, à vida em comunhão com a arte. Enfim, elementos que permitam visualizar um ato performático em processo, no espelhamento do homem e do poeta.

\section{oswald de andrade: um problema literário}

Oswald de Andrade foi poeta, dramaturgo, romancista, jornalista e articulista. Em qualquer uma dessas atividades, ele chama a atenção de leitores e pesquisadores por sua verve transgressiva, irreverente e satírica - o escritor que desafiou as convenções sociais, morais e literárias na provinciana São Paulo do começo do século XX. Moço de família rica de produtores de café, trazia de suas viagens à Europa os novos paradigmas 
artísticos de Marinetti, Breton, Tzara, Cendrars. Foi um dos idealizadores da Semana de Arte Moderna (1922) e um dos mais empenhados em romper com a academia e com o passadismo literário.

Em "Um retrato do artista", seção do livro Por que ler Oswald de Andrade, Maria Augusta Fonseca compõe um breve perfil do modernista:

Conhecido por sua personalidade exuberante e indômita, Oswald de Andrade sempre manteve em alerta o espírito barulhento e combativo. Veemente nas intervenções públicas, o artista enfrentou desafios e vaias, rebatendo com sua irreverência desconcertante (FONSECA, 2008, p. 11).

Maria Augusta destaca o retrato que Oswald de Andrade construiu de si mesmo ao longo de sua trajetória literária: o iconoclasta desbocado, que não fugia de uma boa discussão sobre literatura ou política. Sua vida pessoal também foi bastante barulhenta para a época, pois o abastado bon vivant escandalizava a sociedade paulistana com seus hábitos pouco ortodoxos, entregue às paixões e à boemia.

Oswald tornou-se símbolo de rebeldia, irreverência e sarcasmo. A imagem que ele carregou até o fim de sua vida e que, certamente, influenciou na recepção de sua obra. Antonio Candido, crítico e amigo do escritor, afirma que

Poucos escritores haverá, tão deformados pela opinião pública e pela incompreensão dos confrades. Em relação à sua obra, os críticos raramente tentam um esforço de simpatia literária, colocando-se acima dos pontos de vista estritamente pessoais. Consideram-no objeto de ataque ou aceitação e correspondem deste modo, consciente ou inconscientemente, ao esforço que ele faz para arrastá-los à polêmica, seu terreno querido (CANDIDO, 1995, p. 42).

As posições críticas de Antonio Candido e Maria Augusta Fonseca encontram respaldo nas palavras do próprio poeta, as quais foram transcritas para a seção "Autorretratos em três por quatro", da antologia A alegria é a prova dos nove (2011), organizada por Luiz Ruffato². De acordo com o organizador,

2 A alegria é a prova dos nove (2011) é uma antologia que recupera trechos de textos proferidos ou escritos por Oswald de Andrade. O responsável pela seleção, organização e apresentação dos textos é o escritor Luiz Ruffato. Trata-se de material revelador do escritor modernista em diferentes momentos de sua trajetória literária. 
"são reflexões de Oswald a respeito de si mesmo, um escritor que não tem fãs e, quando distribui autógrafos, é aos pregos e aos bancos" (2011, p. 16-17):

Na solidão sou soturno e amlético [sic]. Em público, sou afirmativo e solar. / Isto é o que quero eu. Vida de Far-West e de preguiça colonial - estética helênica e renascentista, eis o querem os outros. / O meu destino é de um paraquedista que se lança sobre uma formação inimiga: ser estraçalhado. / Quando é pra falar mal, falo mal até de minha própria família. Toda a minha vida se pautou por uma grande lealdade a mim mesmo. / Do meu fundamental anarquismo jorrava sempre uma fonte sadia, o sarcasmo [...]. / Gosto de propor os meus pontos de vista, ensinar o que sei, ainda que errado, e intervir mesmo no que não sei (OSWALD DE ANDRADE apud RUFFATO, 2011, p. 141-143).

O gosto pela polêmica e embates com a crítica literária rendeu ao poeta de Pau-Brasil muitos desafetos, conforme afirma Candido. O modernista foi vítima do mito que ele mesmo criou, uma vez que sua fama muitas vezes o antecedia (ou ainda continua antecedendo). Visto como objeto de ataque pelos simpatizantes da literatura acadêmica, sua poesia era muitas vezes interpretada como cópia das estéticas vanguardistas e de questionável valor literário. A busca pelo reconhecimento de sua obra, principalmente de sua poesia, acompanhou-o até o final de sua vida.

Em vista do perfil complexo e, em certa medida, inapreensível do escritor, o crítico Antonio Candido, em "Estouro e libertação" (1995, p. 41), alerta os pesquisadores de que "Oswald é um problema literário" e, como tal, imagina "as rasteiras que passará nos críticos do futuro". Candido referese a estudos conduzidos por uma visão simplista e apressada do autor, que valoriza o mito em detrimento da análise objetiva de sua produção, o que acaba promovendo uma leitura mecânica vida-obra.

Sabemos que é difícil não se deixar conduzir pela vida "romanceada" do autor de Um homem sem profissão sob as ordens de mamãe (1954). Mas precisamos considerá-la como forma de apreender certos aspectos que passariam despercebidos, caso não o fizéssemos. Sua história não pode ser desprezada da análise do poema, pois esses elementos concorrem para a construção da subjetividade e promovem, em alguma medida, a comunicação do homem e poeta Oswald de Andrade com o "eu" ficcional. 


\section{"reivindicacão": performatividade e desdobramento}

Poesias reunidas Oswald de Andrade (2017), em sua última edição, apresenta 22 poemas (inéditos até a data de sua publicação) do poeta Oswald de Andrade, os quais estavam dispersos entre seus familiares ou amontoados no fundo de uma gaveta. O certo é que o autor deixou de publicá-los por alguma razão que desconhecemos. Jorge Schwartz, crítico e organizador da nova edição, reconhece o valor estético desses poemas:

Oswald foi moderno e hoje é contemporâneo. Pau Brasil foi uma ruptura com o cânone da poesia em língua portuguesa. Se hoje a 'apropriação' é assunto crucial nas artes visuais, Oswald soube se apropriar de vários tipos de discursos, para transfigurá-los em poesia (SCHWARTZ, O Globo, 28/01/2017).

Os poemas inéditos ajudam a pensar o modernista não apenas restrito aos ideais da Semana de Arte Moderna ou como o escritor que incomodava pela ousadia ou deboche. Eles vêm com a força de reafirmar a importância e a contemporaneidade de sua poesia. Como se sabe, os princípios da poesia oswaldiana foram reaproveitados por vários artistas, em diferentes épocas. Eles convocam, através de sua arte, o discurso revolucionário e minimalista do poeta com vistas a propor uma composição poética de linguagem dinâmica e plural, em diálogo com o contemporâneo. A síntese, a piada, a ironia, a crítica, a linguagem coloquial e fragmentária são recursos, que atualmente servem a poetas como Francisco Alvim e Arnaldo Antunes, os quais procuram agregar esses recursos às diferentes linguagens e discursos do cotidiano com a intenção de criar uma literatura em sintonia com seu tempo.

Nesse sentido, a publicação de Poesias reunidas Oswald de Andrade (2017) apresenta-se como mais uma oportunidade de refletir sobre a poesia oswaldiana, já que o livro inclui toda a criação poética do escritor. Desse conjunto, os poemas inéditos merecem um olhar mais atento, pois abrem caminhos para atestar a contemporaneidade dessa poética, além de provocar novas discussões sobre a trajetória literária e pessoal do poeta paulista.

A organização desses textos obedece a uma sequência cronológica atribuída pelos organizadores da coletânea, Gênese Andrade e Jorge Schwartz. São mais de vinte anos de composição poética (1920 - 1944), oferecendo 
um painel bastante variado de temas, recursos expressivos de linguagem e experimentalismos formais. Os poemas são prova da mobilidade e inventividade com que o escritor conduzia o processo de criação poética. Do conjunto, optamos por trabalhar com "reivindicação", contemporâneo dos poemas Pau-Brasil:

\author{
Que pena \\ Não achar \\ Aquele poema \\ Que eu fiz \\ Antes de todos \\ Os poemas \\ De Mário de Cendrars de Luiz Aranha e de Manuel \\ Eu trabalhei \\ Com um cinzel retardatário \\ Era o último passeio em 20 anos \\ De um tuberculoso \\ Pela cidade \\ De bonde \\ Dlen! Dlen! \\ Eu o poria neste papel \\ (2017, p. 221).
}

Esse texto foi escrito, provavelmente, na década de 1920. Uma época marcada por uma profícua produção poética e lançamento de dois manifestos: PauBrasil (1925) e Antropofagia (1928). Possivelmente, o texto em estudo oferecerá "pistas" de sua inserção nesse cenário de renovação da literatura brasileira.

As escolhas teóricas para esta leitura crítica, ajudam-nos a pensar o lirismo na modernidade e o papel que o sujeito lírico assume nesse contexto. Hugo Friedrich, em Estrutura da lírica moderna: dissonâncias e anormalidades (1978), trata das tensões dissonantes ocorridas na poesia lírica moderna, as quais subvertem o lirismo hegeliano. G. W. Friedrich Hegel (1993, p. 616) defende que a atividade do poeta "deve limitar-se a deixar falar a interioridade, qualquer que seja o tema, contando que as palavras proferidas sejam a expressão da alma do poeta, da sua vida espiritual [...]". Hegel 
entende que o poema lírico deve ser uma extensão do poeta que representa a si mesmo. Dessa forma, o texto lírico é o lugar de expressão do poeta, no qual sujeito lírico e sujeito empírico são vozes indissociáveis. Quando o texto de Hugo Friedrich (1978) fala em "dissonâncias" e "anormalidades", alude às superadas "consonâncias" e "normalidades" da lírica tradicional, preconizada por Hegel no capítulo "A poesia lírica", de Estética (1993).

Friedrich aponta como tensões dissonantes da lírica moderna: os aspectos formais, linguísticos, de conteúdo, a relação poesia e leitor e a atuação do poeta e do sujeito lírico. O poema lírico não é mais a expressão do estado de alma do poeta, mas um trabalho, "construção sistemática de uma arquitetura, operação com os impulsos da língua" (FRIEDRICH, 1978, p. 39). A despersonalização, o apagamento do eu empírico, faz parte desse trabalho intelectual, que possibilita o abandono do tom confessional de representação do poeta, a fim de transformar a poesia lírica em espaço de criação, dando voz a outros eus.

Sobre a nova configuração do sujeito na contemporaneidade, contamos com as contribuições de Fabíola Padilha (2014), Flora Süssekind (2002), Dominique Combe (2009-2010), Michael Hamburger (2007). Esse aporte teórico fundamenta a discussão sobre subjetividade lírica e performances subjetivas. Fabíola Padilha, em "Que reste-t-il du sujet? Performances subjetivas na poesia brasileira contemporânea" (2014), anuncia o retorno do sujeito à poesia na contemporaneidade, questionando: "como se apresenta e se configura o sujeito que se inscreve, performando-se, no interior dos poemas?" (PADILHA, 2014, p. 179). Flora Süssekind, em Papéis colados (2002), apresenta o sujeito lírico ${ }^{3}$ como instrumento de "fingimento" do poeta. A autora ainda aponta fundamentos para essa definição: "Primeiro, o destaque do fingir, da construção de uma máscara lírica no poema. Segundo: a repetição dos índices de primeira pessoa, indicando que é ao 'eu' que se refere o fingimento. Um eu que o poeta produz ficcionalmente $[. . .]^{\prime \prime}$ (SÜSSEKIND, 2002, p. 315).

Michael Hamburger, em A verdade da poesia (2007), destaca que os poetas modernos "recorreram a máscaras a fim de fazer do homem só na multidão, da identidade negativa, a multiplicidade positiva ou a universalidade do ser"

3 O termo "máscara" assume o sentido de disfarce, fingimento poético. Funciona como recurso expressivo do qual escritores da modernidade lançaram mão como estratégia de apagamento do sujeito empírico em seus poemas. 
(p. 107). Dessa forma, o sujeito empírico pode ser diluído em sujeitos líricos distintos, o que oportuniza ao poeta investir em variadas performances. Dominique Combe, em A referência desdobrada: o sujeito lírico entre a ficção e a autobiografia (2009-2010), dá continuidade à discussão sobre o sujeito lírico, afirmando que literatura e biografia são inseparáveis pelo grau de referencialidade da obra literária. Se literatura e biografia caminham juntas, segundo o estudioso, como reconhecer o tipo de sujeito em performance?

Refletir sobre uma possível aproximação entre os sujeitos lírico e empírico implica questionamentos que direcionarão este trabalho: Em que medida o poeta conseguiu anular o eu empírico no poema "reivindicação"? O sujeito lírico desvincula-se totalmente do sujeito empírico? O sujeito lírico não seria um desdobramento do sujeito empírico em performance? O ficcional e o autobiográfico estariam ali imbricados, espelhando vida e obra de Oswald de Andrade? Diante dessas inquietações, a partir de agora, desenvolveremos uma reflexão que busque o vínculo, muitas vezes oculto pelo fingimento poético, do poeta vanguardista com o sujeito lírico em performance no texto.

A matéria poética de "reivindicação" é a própria poesia modernista, identificada não só pelos aspectos formais e linguísticos, como também pela presença de alguns nomes de proa do nosso Modernismo: Mário de Andrade, Blaise Cendrars, Luiz Aranha e Manuel Bandeira. Embora filiado aos padrões vanguardistas da época, o poema apresenta certas dissonâncias e ambivalências que merecem ser apontadas. Elas são indicadores do jogo performático pensado por Oswald como forma de construir uma estratégia de "convencimento" e chamar a atenção para o objeto reivindicado.

Seguindo caminho inverso às tendências da lírica moderna, o poema começa em tom confessional, simulando o estado de ânimo do sujeito em enunciação. Hugo Friedrich, em Estrutura da lírica moderna (1991), sobre as dissonâncias e anormalidades que a constituem, afirma que

É justamente esta intimidade comunicativa que a poesia moderna evita. Ela prescinde da humanidade no sentido tradicional, da 'experiência vivida', do sentimento e, muitas vezes, até mesmo do eu pessoal do artista. Este não mais participa em sua criação como pessoa particular, porém como inteligência que poetiza, como operador da língua, como artista que experimenta os atos de transformação de sua fantasia imperiosa ou de seu modo irreal de ver num assunto qualquer, pobre de significado em si mesmo. (FRIEDRICH, 1991, p. 17). 
O escritor de Serafim Ponte Grande (1933) sempre se lançou destemido contra qualquer tipo de acomodação ou atraso, não só no âmbito da literatura, mas também da política e cultura brasileiras. Como poeta da modernidade, leitor de Eliot e Pound, entre outros, seria coerente que optasse pela despersonalização e evitasse a "intimidade comunicativa" com texto e leitor. Porém, percebemos, por aspectos textuais, que essa intimidade ocorre pela provável autorreferencialidade e pela metalinguagem. O autorreferencial pode ser compreendido pela presença de elementos vinculados ao próprio poeta, enquanto o metalinguístico, por tratar-se de um poema cujo mote é a própria criação poética. Em certa medida, considerando esses dois conceitos, é possível alcançar o sujeito empírico presente no poema "reivindicação".

O uso da $1^{\text {a }}$ pessoa deflagra subjetividade e emotividade em qualquer poema, mas não garante a presença do poeta no texto. Em "reivindicação", essa escolha adequa-se à imagem fragilizada do sujeito lírico, representada no verso: "Que pena". O "eu" ficcional criado pelo poeta veste a máscara de um jovem e infeliz poeta que perdeu seu primeiro poema livre e que sonha ver seu nome figurando entre os grandes poetas do Modernismo brasileiro.

Voltando ao trecho de Friedrich (1991, p. 17), Oswald foi capaz de transformar um fato corriqueiro (a perda de um poema), em material poético, ampliando seu significado, ao trazê-lo para determinado momento de nossa literatura. Isso seria normal, tratando-se de uma "inteligência que poetiza", de um "operador da língua", de um "artista" como Oswald de Andrade. Mas o que ocorre, na verdade, é um discurso planejado com engenhosidade e com um propósito bem definido pelo poeta transgressor. Nos quatro primeiros versos: "Que pena / Não achar / Aquele poema / Que eu fiz / Antes de todos I Os poemas [...]", o ressentimento pela perda do poema é um artifício que mascara a verdadeira intenção do "eu" - conquistar um lugar de destaque frente aos outros poetas modernistas. É o jogo de mostrar e simular do fingimento poético, o qual funciona como "estratégia de convencimento" no alcance do objetivo.

O poema enquanto discurso também constitui uma máscara cuja arquitetura coaduna-se com os propósitos do sujeito empírico. Quanto à tipologia, a reivindicação é um texto formal, cuja estrutura obedece a determinadas regras de composição. Oswald dessacraliza essa forma rígida e compõe sua "reivindicação" em versos livres, utilizando variados 
recursos expressivos como a interdiscursividade e a intertextualidade. A interdiscursividade faculta ao poeta recuperar o título do poema perdido para fragmentá-lo em versos e convocar outros discursos nas pessoas "De Mário de Cendrars de Luiz Aranha de Manuel". Esse verso longo retoma o primeiro momento modernista e a importância desses poetas na luta pela renovação literária. É uma enumeração sem pontuação, propositadamente à moda de Bandeira, nos versos de "Poética", verdadeiro manifesto antipassadista. $O$ verso longo de Oswald também reitera sua adesão aos movimentos de vanguarda, no caso, ao Futurismo de Marinetti.

Outros discursos são convocados pelo poeta em viés crítico e irônico. Os versos "Eu trabalhei / Com um cinzel retardatário" é uma referência ao poeta parnasiano Olavo Bilac e ao poema "Profissão de fé", um dos textos mais conhecidos e representativos do Parnasianismo brasileiro. As palavras "trabalhei" e "cinzel" aludem ao labor do joalheiro, no caso, uma metáfora do poeta parnasiano em seu fazer poético ("Por isso, corre, por servir-me, I sobre o papel / A pena, como em prata firme / Corre o cinzel"). Ao mesmo tempo, pode-se ler os mesmos versos em chave irônica e desencantada, o que permitiria pensar na blague modernista, especialmente na inversão: "Eu trabalhei / Com um cinzel retardatário", porque o adjetivo "retardatário" é antítese de "precursor". Eis o contraditório e o ambivalente. No texto "Poéticas da lucidez: notas sobre os poetas críticos da modernidade" (1994), Maria Esther Maciel comenta que a ironia, na modernidade, torna-se é uma ferramenta importante no processo de criação da poesia crítica:

A ironia, tal como foi concebida pelos românticos, torna-se um conceito fundamental dentro desse processo: não mais entendida como um mero recurso de retórica, mas sistematizada enquanto um sofisticado artifício literário, ela permite ao poeta distanciar-se criticamente de sua obra e ao mesmo tempo nesta introduzir o seu ato de distanciamento, possibilitando, assim, não apenas a disjunção entre sujeito poético e sujeito empírico, como também a relação dialógica entre exame crítico e criação poética (p. 77).

Esse diálogo entre exame crítico e criação poética é o que ocorre nos dois versos citados anteriormente. Eles funcionam como uma pequena pausa para o "eu" refletir e lamentar o seu atraso em relação aos outros poetas. No poema em estudo, o distanciamento funciona como recurso crítico 
direcionado aos outros - os parnasianos - e ao sujeito empírico. Há outros trechos de "reivindicação", que também merecem destaque: o verso "Antes de todos os poemas" insinua a pretensa precedência do poeta sobre os pares, embora o título do "poema pioneiro" ressoe temas penumbristas - "O último passeio de um tuberculoso pela cidade, de bonde". Ironicamente, o título do exaltado poema guarda vestígio do Romantismo ainda não superado pelo suposto precursor.

Reconhecemos como performances ou atos performáticos a atuação do poeta, sujeito empírico, na construção do poema "reivindicação". Observamos que ele utiliza diversos recursos estilísticos que denotam sua inserção na modernidade: Oswald aproveita-se das dissonâncias e anormalidades da poesia moderna e monta um texto sintético e fragmentário, de fundo argumentativo, que questiona o próprio fazer poético de forma crítica e irônica, trazendo para a discussão poetas consagrados do Modernismo. Além disso, aproveita o tema metalinguístico para "alfinetar" a estética romântica e parnasiana. Oswald de Andrade entende assim o papel do escritor:

Estou convencido de que deve ser essa a atitude de quem escreve: reagir, disputar o seu lugar ao sol e atacar sem hesitações a inveja que assedia todo o êxito legítimo. (OSWALD DE ANDRADE apud RUFFATO, 2011, p. 93).

Romain Rolland ensinou a nós todos que escrevemos, este primeiro dever: saber o que queremos, onde estamos, para onde vamos e como devemos agir. Coisas que evidentemente o literato de café prefere ignorar. (OSWALD DE ANDRADE apud RUFFATO, 2011, p. 94).

O escritor que não desce à rua, que não briga com o condutor do bonde por causa do troco, não joga no bicho, não torce no futebol, é um pobre-diabo, que antes merece nossa comiseração, que crítica (OSWALD DE ANDRADE apud RUFFATO, p. 95).

O poema "reivindicação" é uma amostra da disposição do próprio poeta em disputar seu lugar na série literária brasileira, contra todos aqueles que divergem de suas ideias e atitudes muitas vezes contraditórias e impactantes. Considerando essa afirmação, voltamos aos questionamentos que norteiam nosso estudo: O sujeito lírico seria um desdobramento do 
sujeito empírico? Há uma conexão entre o ficcional e o autobiográfico? De quem é a voz encenada no poema? O sujeito empírico realmente cedeu sua voz a outro sujeito? Iniciaremos outra parte da análise de "reivindicação", com a apresentação de alguns dados biográficos do escritor, os quais nos ajudarão a pensar tais indagações.

Começaremos situando o poema em seu contexto histórico e cultural. "reivindicação" retoma o primeiro texto lírico escrito por Oswald de Andrade quando retornou da Europa, em 1912. Se o texto foi perdido por ele e não há cópias, como confirmar a veracidade dessa informação? Em seu livro de memórias, Um homem sem profissão: sob as ordens de mamãe (1954), o poeta refere-se a essa primeira poesia e insinua que ele poderia ter sido o desencadeador da renovação modernista no Brasil:

Uma aragem de modernismo vinda através da divulgação na Europa do 'Manifesto Futurista', de Marinetti, chegara até mim. Tentei um poema livre. Guardo até hoje o seu título. Chamava-se ' $O$ último passeio de um tuberculoso, pela cidade, de bonde'. Mas a assuada dos Define me fez jogar fora o poema e com ele qualquer esperança de ver nossa literatura renovada. Entre velhos e novos não encontrei um só escritor que nessa época me animasse na intenção de renovar letras e artes (ANDRADE, 1990a, p. 84-85).

Em depoimento concedido ao Correio Paulistano (26/06/1949), Oswald narra seu encontro com Mário de Andrade, em 1917 e, claro, dá mais importância ao fato de ter destruído o primeiro poema livre escrito em terras brasileiras:

A essa altura, Mário já tinha um livro publicado - Há uma gota de sangue em cada poema -, que passara em branca nuvem. As poesias se conformavam com a moda dominante, mas havia na coleção um verso que me interessou: ' $O$ vento faz ô ô ô'. Eu já tinha estado na Europa, onde tomara conhecimento, em Paris, do Manifesto Futurista de Marinetti e assistira à coroação de Paul Fort, que foi um revolucionário da forma poética, como príncipe dos poetas franceses. Regressei a São Paulo em 1912, achando que a poesia brasileira podia ser mais avançada, adotando, inclusive, o verso livre. Fiz mesmo um poema, de que infelizmente não tenho cópia, chamado o 'Último passeio de um tuberculoso pela cidade, de bonde'. Mostrei-o aos rapazes de $\mathrm{O}$ Pirralho, mas fui tão arreliado que o joguei fora. Quando encontrei o verso de Mário de Andrade e, mais tarde, o poeta me 
leu alguns trechos da Pauliceia Desvairada, vi em sua poesia uma confirmação dos caminhos que eu desejava (ANDRADE, 1990b, 149).

Em ambos os relatos, Oswald se apresenta como um modernista avant la lettre. Ele foi o escritor brasileiro que entrou em contato com a vanguarda futurista na Europa e não Mário ou outro qualquer. Ele teve a ideia de escrever o primeiro poema livre, seguindo os vanguardistas europeus. Logo, ele se considerava precursor do Modernismo no Brasil. Caso o poema não tivesse sido destruído por Oswald, haveria alguma coerência nessa premissa? É evidente que uma primeira tentativa de poema livre, de repisado tema romântico, não teria o poder de alterar os paradigmas literários daquela época. Como o "eu" de "reivindicação", o poeta modernista também reclama o lugar de destaque e de direito que acredita possuir entre os poetas brasileiros.

Mário de Andrade e o franco-suiço Blaise Cendrars são escritores que compartilharam com Oswald de Andrade o mesmo sentimento pela cultura e história brasileiras e contribuíram com o projeto Pau-Brasil. Esses intelectuais foram fundamentais no processo de renovação literária que o escritor de Ponta de lança (1945), com falsa modéstia, pretendia iniciar a partir de seu tímido poema de versos livres. Em entrevista de 1950, Oswald reconhece a importância de Mário de Andrade em sua formação literária: "Mário foi um grande estímulo e, sob certo aspecto, gostei dele por narcisismo, pois a sua literatura vinha provar que as minhas tendências eram certas" (ANDRADE, 1990b, p. 163).

O poema "reivindicação" funciona como instrumento de autoafirmação do modernista de primeira hora - necessidade recorrente durante sua trajetória - perante modernistas consagrados, sobretudo Mário de Andrade e Manuel Bandeira. Interessante observar que ele mesmo, Oswald de Andrade, pouco modesto e narcisista, afirma ter gostado da poesia de Mário, por enxergar nela o reflexo da sua. "reivindicação" delineia o perfil do autor de Poesias reunidas: aquele que chama para si todas as glórias e todo reconhecimento pela inovação das artes brasileiras; aquele que vê na perda do poema de juventude um mote para um poema livre crítico e irônico.

O poema que ajudou a compor outro poema, mas com uma intenção definida e bem articulada. O escritor prioriza a agilidade da linguagem da poesia substantiva, utilizando poucos recursos estilísticos e evitando elementos 
qualitativos. Seja como for, o poema escrito em 1912 é aqui "recuperado" como início de uma carreira literária desde o começo empenhada em fazer poesia revolucionária: o tom confessional do início é substituído pelo dinamismo futurista festejando a passagem do bonde: "Dlen! Dlen!" ou, ainda, de sua poesia radical, como se dissesse: "Abram caminho para o modernista Oswald de Andrade!".

Sabemos que o poema "reivindicação" foi elaborado quando Oswald gozava de prestígio entre seus pares. Hoje somos capazes de visualizar através dele o poeta e sua trajetória literária. Portanto, podemos afirmar que há sim uma imbricação entre o ficcional e o autobiográfico no poema em estudo. Um possível leitor do começo do século XX não conseguiria fazer essa leitura e, possivelmente, imaginasse tratar de mais uma brincadeira, uma provocação do irreverente poeta modernista. Porém as marcas autobiográficas são evidentes, como foi demonstrado nos trechos de Um homem sem profissão (1954) e nos depoimentos dados a jornais (anos 40 e 50).

Paul Éluard (1968, p. 934), citado por Dominique Combe em "A referência desdobrada: o sujeito lírico entre a ficção e a autobiografia" (2009-2010), nomeia os poemas autobiográficos ou que tenham marcas autobiográficas como de circunstância, porque "se inspiram na realidade, é na realidade que eles se fundam e repousam [...]". Os poetas de circunstância deixam que seu "eu" referencial exprima-se livremente e, sobre eles, Paul Éluard comenta: "sabemos as circunstâncias de suas vidas e sabemos que sua obra é função dessas circunstâncias" (2009-2010, p. 121). É comum na obra de Oswald de Andrade a associação vida e arte transfigurada ficcionalmente por variadas performances, como no poema "reivindicação". A circunstâncias da vida oferecem a matéria poética: "Vida e obra de um escritor são a mesma coisa. Principalmente quando ele é sincero. Quando nada esconde" (OSWALD DE ANDRADE apud RUFATTO, 2011, 95).

Quanto ao desdobramento sujeito lírico e sujeito empírico, não podemos confirmar que o sujeito empírico, sob a máscara de um sujeito lírico ficcional, está inteiro no poema. Presumimos que o sujeito em enunciação no poema funciona como um porta-voz do poeta, atuando como produto de sua "restância". Fabíola Padilha em "Que reste-t-il du sujet? Performances subjetivas na poesia brasileira contemporânea" (2014) utiliza o termo "restância" para falar do retorno do autor à poesia contemporânea, visto sob a perspectiva da autoficção, dos textos de instância autoral, da literatura de 
testemunho etc. Para a estudiosa, o "eu" que retorna na contemporaneidade é a sobra ou resto do exercício de apagamento do sujeito ocorrido a partir de Baudelaire, final do século XIX. Como sobra ou resto, o poeta permanece no poema, mesmo que ficcionalmente ausente.

Esse "eu" resíduo, segundo ela, está "[...] no limiar da contradição experimentada na contemporaneidade, entre um "eu" que insiste em se fazer notar e a indigência de plenitude" (2014, p. 183). É dessa tensão dissonante que nascem as performances subjetivas. Performance é arte em processo e como tal, proporciona ao sujeito a capacidade de transformação, de estar sempre em processo de criação. É nesse jogo ininterrupto de mostrar e simular que se instalam as performances subjetivas "nas mais diversas ficções do eu". O quadro abaixo ilustra esse processo:

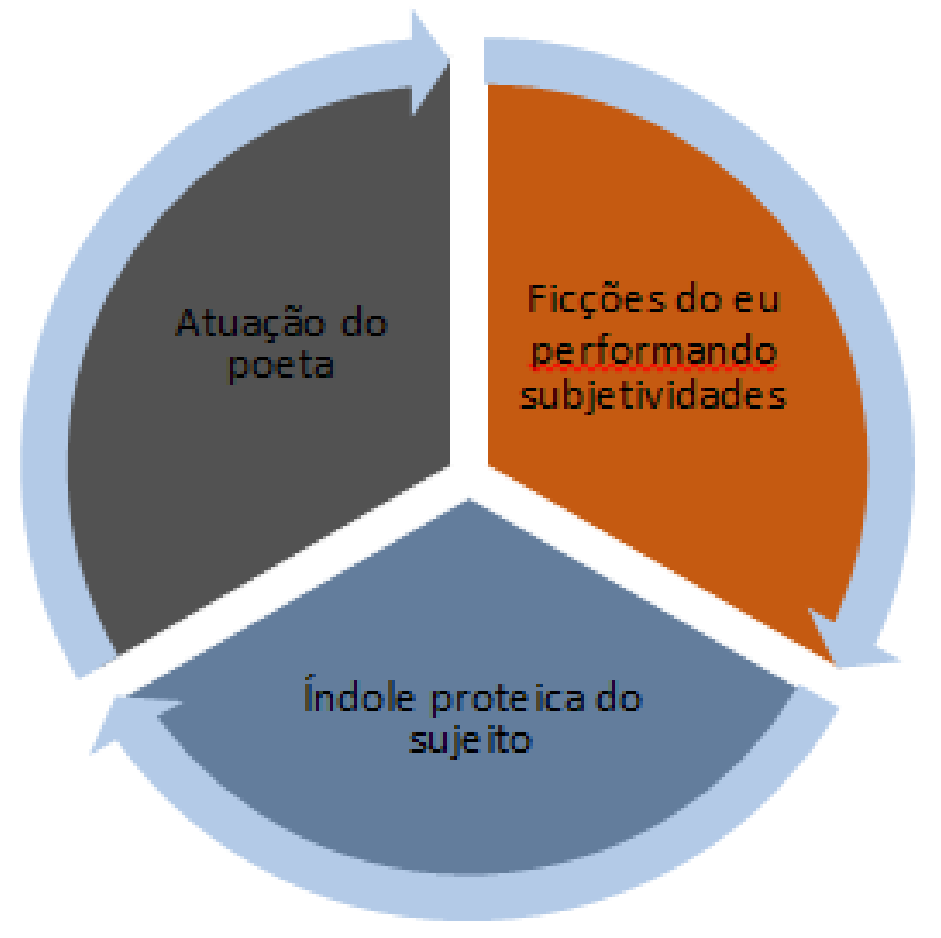

O sujeito lírico do poema "reivindicação" é criado em função do poema no papel de um "eu" reivindicador que representa o sujeito empírico. O "eu" ficcional atua como uma extensão do "outro" presente apenas em resíduos, em retalhos de vida espalhados pelo poema. Essas marcas, também atos performativos, são colocados ali com a finalidade de conectar o ficcional ao autobiográfico, enquanto traz o sujeito empírico, em chave irônica, para o espaço que antes Ihe pertencia. Mesmo como resíduo, Oswald de Andrade ocupa todo o espaço do texto.

Flora Süssekind comenta sobre a presença do sujeito no poema, a partir de dois versos citados em Papéis colados (2002, p. 317): "Eu no pensar me finjo", 
de Leopardi; "Eu arranho como um gato", de Sylvia Plath. Para a autora, "um eu que se define como fingimento dialoga com outro que sequer se define, apenas 'lacera'. E cujas fraturas, cujos pedaços de ego arranhamse como gatos. E, de tão lacerados [...], talvez tenha se tornado impossível até 'fingir-se'". A observação de Süssekind pode ser estendida ao fingimento poético que se realiza no poema "reivindicação": o sujeito lírico, sob a máscara de um jovem poeta, dialoga com o poeta Oswald de Andrade, cujos "pedaços de ego" encontram-se diluídos nos versos. É difícil não perceber a presença de um escritor que, de acordo com Antonio Candido (1995, p. 86-87), "[...] escandalizava pelo fato de existir, porque sua personalidade excepcionalmente poderosa atulhava o meio com a simples presença". Passar despercebido era algo intolerável para o autor da Poesia Pau-Brasil.

Adespersonalização-dissonância dalírica moderna-impõe ao poeta moderno o apagamento de si. Isso faz com que o poeta, sujeito empírico, invista na criação de personas ou máscaras que forjam identidades antagônicas a ele mesmo. Por ser uma relação conflituosa, acaba aumentando a distância entre o experimentado e o imaginado. Michael Hamburger, em $A$ verdade da poesia (2007), no capítulo "As máscaras", faz uma análise das variadas formas de despersonalização utilizadas por grandes poetas modernos e confirma que

[...] a primeira pessoa num poema lírico jamais deveria ser identificada, em qualquer caso, ao eu empírico do poeta. Quer fundamentalmente confessional quer fundamentalmente dramática, a primeira pessoa na poesia lírica serve para transmitir um gesto, não para documentar a identidade nem estabelecer fatos biográficos. Só quando os poetas se esquecem disso é que a primeira pessoa se torna 'egoísta' e, não raro, entediante (HAMBURGER, 2007, p. 115).

"reivindicação" não atende aos preceitos de Hamburger. Oswald tenta fazer o que a época exige, contudo, nesse poema, o "eu" atrás da máscara termina por estreitar os laços entre experiência empírica e experiência imaginativa. Os sujeitos não se excluem; pelo contrário, eles se aglutinam em torno de uma mesma ideia e lutam pelo mesmo objetivo. Um é a extensão do outro. Um é a voz do outro. Um é o desdobramento do outro em performance. 


\section{consideracões finais}

Mesmo sendo um poema curto, fragmentado e de linguagem sintética, "reivindicação" diz muito sobre o Modernismo brasileiro, sobretudo sobre a relação nem tão tranquila entre os escritores da geração de 22 . É claro que estavam unidos e coesos em torno da ideia de destruir o passadismo literário; mas, ao mesmo tempo, cada um deles disputava seu "lugar ao sol" na série literária brasileira, buscando consolidar sua carreira de poeta da modernidade com produções literárias que refletissem os princípios da nova estética.

É um período muito produtivo, mas de muitas tensões e, consequentemente, de acertos e erros, de afetos e desafetos, principalmente quando se trata do escritor Oswald de Andrade, visto que sua poesia é resultante desse contexto, absorve toda a agitação do momento e a retrata sob o olhar transgressor de poeta performático. Em "reivindicação", o poeta disputa seu lugar de precursor do Modernismo brasileiro pelo simples fato de ter viajado para a Europa, entrado em contato com a vanguarda futurista e ter escrito, segundo ele, um pequeno poema em versos livres logo depois que voltou de viagem, em 1912.

Egocêntrico e narcísico, Oswald gosta de chamar a atenção para si e seus feitos, sejam literários ou não. O mérito para o poeta é ser apontado como autor do primeiro poema moderno escrito no Brasil, antes de grandes poetas brasileiros, principalmente Mário de Andrade e Manuel Bandeira, com os quais se desentendeu anos depois da Semana de Arte Moderna. Oswald apega-se somente a datas e não à qualidade e filiação de sua poesia à estética modernista. Realmente, os outros escritores começaram a trilhar os novos caminhos a partir de 1917 ou mais tardiamente ainda, porém, esse dado não autentica a Oswald o "título" de precursor da modernidade brasileira na literatura.

Conforme discutido durante este estudo, o poema espelha o poeta Oswald de Andrade performando subjetividades por meio de aspectos linguísticos, formais e temáticos. Como índice argumentativo, convoca outras vozes (poetas modernistas e o parnasiano Olavo Bilac), as quais fortalecem sua reivindicação e proporcionam ao poeta Pau-Brasil lançar mão de recursos que the são peculiares, como a crítica, a ironia e o sarcasmo. Mas nada disso seria mais indispensável à sua reivindicação do que um sujeito lírico no papel 
de seu porta-voz. Através dele, Oswald pôde reivindicar e, ao mesmo tempo, desferir críticas e ironias a quem as merecesse.

A análise confirma a fusão do ficcional e do autobiográfico pelo grau de referencialidade do poema. Fatos e pessoas citadas realmente fizeram parte da história de Oswald de Andrade, no entanto foram trazidos como matéria poética e passaram pelo crivo da ficção. Dessa forma, não há como fugir do desdobramento sujeito lírico-sujeito empírico que, embora disfarçado pelo uso de uma máscara ficcional, do jogo performático em curso desde o primeiro verso, não conseguiu esconder os retalhos do poeta espalhados por todo o poema. Oswald não conseguiu fingir bem. Usou o outro "eu" para se esconder e acabou arranhando, ou melhor, lacerando todos nós "com sua personalidade excepcionalmente poderosa" (CANDIDO, 1995, p. 86-87).

\section{referências}

ANDRADE, Oswald de. Poesias reunidas Oswald de Andrade. São Paulo: Companhia das Letras, 2017.

Um homem sem profissão: sob as ordens de mamãe. São Paulo: Globo; Secretaria de Estado da Cultura, 1990a. (Obras Completas de Oswald de Andrade).

. Os dentes do dragão: entrevistas. Org. M. E. Boaventura. São Paulo: Globo; Secretaria de Estado da Cultura, 199ob. (Obras Completas de Oswald de Andrade).

CANDIDO, Antonio. Estouro e libertação. In: Vários escritos. 3. ed. rev. e ampl. São Paulo: Duas Cidades, 1995.

COMBE, Dominique. A referência desdobrada: O sujeito lírico entre a ficção e a autobiografia. Tradução de Iside Mesquita e Vagner Camilo. Revista USP, São Paulo, n. 84, p. 112-128, dez./fev. 2009-2010.

FONSECA, Maria Augusta. Por que ler Oswald de Andrade. São Paulo: Globo, 2008. (Coleção Por que ler).

FRIEDRICH, Hugo. Estrutura da lírica moderna. São Paulo: Duas Cidades, 1991. 
HAMBURGER, Michael. As máscaras. In: A verdade da poesia: tensões na lírica modernista desde Baudelaire. Tradução de Alípio Correia de Franca Neto. São Paulo: Cosacnaify, 2007. p. 89-115.

HEGEL, G. W. Friedrich. II. A poesia lírica. In: Estética. Tradução de Álvaro Ribeiro e Orlando Vitorino. Lisboa, PT: Guimarães Editores, 1993. p. 607-627.

MACIEL, Maria Esther. Poéticas da lucidez: notas sobre os poetas-críticos da modernidade. Revista Estudos de Literatura, Belo Horizonte, v. 2, p. 75-76, out. 94 .

PADILHA, Fabíola. Que rest-t-il du sujet? Performances subjetivas na poesia brasileira contemporânea. In: CURTIS, Alexandre; CARVALHO, Raimundo; SALGUEIRO, Wilberth (Orgs.). Todos os poemas o poema. Vitória: EDUFES, 2014, p. 179-193.

RUFFATO, Luiz. A alegria é a prova dos nove: Oswald de Andrade. São Paulo: Globo, 2011.

SCHWARTZ, Jorge. Livro "Poesias reunidas", de Oswald de Andrade, traz 22 poemas inéditos. O Globo, 28/01/2017. Entrevista concedida a Leonardo Cazes. Disponível em: <https://oglobo.globo.com/cultura/livros/ livro-poesias-reunidas-de-oswald-de-andrade-traz-22-textosineditos-20835829>. Acesso em: 20/01/2020.

SÜSSEKIND, Flora. Ego trip. Uma pequena história da metamorfose do sujeito lírico. In: . Papéis colados. 2. ed. Rio de Janeiro: Editora UFRJ, 2003. p. 305-318.

Artigo recebido em: 20/01/2020 Aceito em: 10/06/2020 